\title{
Literature Review: Mekanisme Resistensi Kemoterapi Berbasis Platinum
}

\section{Literature Review: Mechanism Resistance of Platinum-Based Chemotherapy}

\author{
Amelia Rizky Khalidah \\ Fakultas Kedokteran, Universitas Lampung, Indonesia
}

ARTICLE INFO

Article history:
Received date
29 Oct 2019
Revised date
06 Dec 2019
Accepted date
24 Apr 2020

Keywords:

Cisplatin;

Mechanism;

Resistence.

Kata kunci:

Cisplatin;

Mekanisme;

Resistensi.

\author{
ABSTRACT/ ABSTRAK
}

\begin{abstract}
Cisplatin is a type of platinum-based chemotherapy that is often used in the spectrum of solid neoplasms, including the ovaries, testicles, urinary vesicles, colorectal, lungs, and head-neck. The clinical success of platinum-based chemotherapy, however, is limited to side effects and the incidence of treatment resistance. Resistance has limited the efficacy of these agents in most diseases, so further knowledge is needed on how the resistance mechanism can occur so that further development can be carried out. Molecular mechanism of cisplatin resistance. Malignant cells can lose their sensitivity to the cytostatic/cytotoxic activity of cisplatin as a result of genetic or epigenetic damage. These changes can affect processes that precede the actual binding of cisplatin to its targets (pre-target resistance), potentiating the cell's ability to repair molecular damage caused by cisplatin (resistance at the target level) and damaging the signal transmission that usually imparts damage caused by cisplatin in apoptosis (post-target resistance) or stimulates pro-survival signaling that counteracts the cytotoxicity of cisplatin even though it usually does not occur by this drug (target resistance).
\end{abstract}

\begin{abstract}
Cisplatin merupakan kemoterapi berbasis platinum yang sering digunakan pada spektrum neoplasms solid, termasuk ovarium, testis, vesika urinaria, kolorektal, paruparudan kepala-leher. Keberhasilan klinis dari kemoterapi berbasis platinum, bagaimanapun, terbatas pada efek samping dan kejadian resistensi pengobatan. Resistensi telah membatasi kemanjuran agen-agen ini pada sebagian besar penyakit sehingga dibutuhkan pengetahuan yang lanjut bagaiman terjadinya mekanisme resisten sehingga dapat dilakukan pengembangan lebih lanjut. Mekanisme molekuler resistensi cisplatin. Sel-sel ganas dapat kehilangan sensitivitasnya terhadap aktivitas sitostatik/sitotoksik dari cisplatin sebagai akibat dari kerusakan genetik atau epigenetik. Perubahan-perubahan ini dapat memengaruhi proses-proses yang mendahului pengikatan aktual cisplatin terhadap target-targetnya (resistensi pra-target), mempotensiasi kemampuan sel untuk memperbaiki kerusakan molekuler yang disebabkan oleh cisplatin (resistensi pada tingkat target) dan merusak transmisi sinyal yang biasanya menyampaikan kerusakan yang diakibatkan cisplatin pada apoptosis (resistansi pascatarget) atau merangsang pengiriman sinyal pro-survival yang melawan sitotoksisitas dari cisplatin meskipun biasanya tidak ditimbulkan oleh obat ini (resistensi target).
\end{abstract}

Corresponding Author:

Amelia Rizky Khalidah

Fakultas Kedokteran, Universitas Lampung, Indonesia

Email: amelia.ai@gmail.com

\section{PENDAHULUAN}

Cisplatin merupakan agen anti-kanker yang sangat efektif dan telah memiliki dampak klinis utama, terutama untuk pasien dengan kanker testis atau ovarium.Oleh karena itu, gelombang pertama aktivitas pengembangan obat anti-kanker adalah menemukan analog yang lebih aman yang mempertahankan aktivitas antikanker. Seluruh obat platinum diberikan melalui bolus injeksi intravena (pada volume besar dalam waktu singkat) atau melalui infus intravena lambat, dan saat obat berada dalam aliran darah, obat akan berikatan dengan serum albumin. Obat-obatan platinum dimasukkan ke dalam sel melalui berbagai mekanisme, terutama 
transporter tembaga, dan transporter tembaga dengan afinitas tinggi. Setelah memasuki sel, konsentrasi garam yang rendah menghasilkan penguapan obat dan hilangnya kelompok zat terlarut obat tersebut (klorida atau ligan berbasis karboksilat) (Oun, et al, 2018).

Mekanisme utama dari cisplatin adalah agen menjadi teraktivasi secara intraseluler oleh akuasi salah satu dari dua kelompok gugus klorida, dan kemudian secara kovalen berikatan dengan DNA, membentuk aduksi DNA. Proses ini mengaktifkan berbagai jalur transduksi sinyal, misalnya, dalam pengenalan dan perbaikan kerusakan-DNA, penangkapan siklus sel, dan kematian/apoptosis sel yang deprogram (Kelland, 2007). Namun, keberhasilan klinis cisplatin terbatas karena efek samping yang besar dan resistensi intrinsik atau yang didapat selama pengobatan. Sayangnya, resistensi telah membatasi efektivitas agen-agen ini pada sebagian besar penyakit. Resistensi terhadap kemoterapi berbasis platinum dapat bersifat intrinsik atau didapat dan dapat dimediasi oleh faktor-faktor di luar atau di dalam sel kanker atau pada membran selnya (Chen \& Chang, 2019).

Resistansi adalah batasan utama dari perawatan obat berbasis platinum karena kanker secara inheren resisten terhadap obat-obatan platium atau dapat mengembangkan resistensi dari waktu ke waktu. Resistensi yang didapat terhadap obat dapat terjadi melalui tiga mekanisme utama yaitu peningkatan degradasi dan penonaktifan obat sebelum mencapai DNA inti, penurunan penyerapan obat ke dalam sel kanker, dan perbaikan DNA yang diperbaiki oleh sel kerusakan yang disebabkan oleh platinum. Resistensi terhadap kemoterapi platinum bersifat multifaktorial sehingga mengetahui mekanisme resistensi memberikan keuntungan untuk pengembangan agen baru dan mengkombinasikan pada agen lainnya (Martin, Hamilton, \& Schilder, 2008).

\section{PEMBAHASAN}

\section{Cisplatin, Kemoterapi berbasis Platinum}

Cisplatin, cis-diammine-dichloroplatinum (II), dikenal sebagai klorida Peyrone sejak akhir abad kesembilan belas (dinamai menurut Michele Peyrone, yang mensintesis pertama kali). Properti sitostatik cisplatin ditemukan oleh Barnett Rosenberg pada akhir 1960-an, ketika ia sedang melakukan percobaan untuk menganalisis efek medan listrik pada pertumbuhan bakteri. Rosenberg dan rekannya mengidentifikasi cisplatin sebagai senyawa kunci yang bertanggung jawab atas efek anti-proliferasi. Uji klinis dimulai pada tahun 1971, dan setelah menghindari beberapa kendala, cisplatin akhirnya disetujui untuk digunakan pada kanker testis dan ovarium oleh Badan Pengawasan Obat dan Makanan AS dan di beberapa negara Eropa pada tahun 1979 (Dilruba \& Kalayda, 2016).

Secara klinis, kompleks platinum digunakan sebagai terapi ajuvan kanker.Tujuan dari terapi anti kanker menginduksu kematian sel tumor. Cisplatin aktif terhadap spektrum luas neoplasma padat, termasuk kanker ovarium, testis, vesika urinaria, kolorektal, paru-paru dan kepala-leher.Agen ini sering digunakan sebagai respon terapeutik awal yang terkait dengan remisi penyakit lengkap, respons parsial, atau stabilisasi penyakit (Dilruba \& Kalayda, 2016).

Meskipun terdapat dampak positif dari komponen platinum, platinum juga bersifat toksik. Pasien yang menerima agen ini akan mengalami efek samping yang sesuai dengan dosis yang diberikan. Kemampuan untuk memanajemen toksisitas merupakan hal krusial untuk kesuksesan kemoterapi. Efek samping dari terapi platinum termasuk kerusakan sel umum, seperti mual dan muntah, penurunan sel darah dan produksi trombosit pada sum-sum tulang (myelosupresi) dan penurunan respon terhadap infeksi (imunosupresi). Lebih jauh lagi, dampak berupa kerusakan pada organ ginjal, saraf, penurunan pendengaran, jantung, dan hepar. Pada toksisitas hepar, platinum meningkatkan peroksidasi lipid dan gangguan status thiol jaringan dengan perubahan antioksidan enzimatik. Glutathione dan kadar glutathione reductase menurun akibat terapi platinum, dimana glutathione peroksidase, gamma-glutamil transpeptidase dan katalase meningkat, sitokrom P450 menurun. Perubahan enzim status antioksidan dengan peningkatan peroksidase lipid mengindikasikan enzim ini berperan penting dalam pmelawan stress oksidatif yang diinduksi oleh radikal bebas (Oun, et al., 2018).

Cisplatin menjadi teraktivasi saat memasuki sel. Pada sitoplasma, atom klorida pada cisplatin digantikan oleh molekul air. Produk yang terhidrolis merupakan elektrofil poten yang dapat bereaksi dengan nukleofil apa saja, termasuk kelompok sulfgidril pada protein dan donor atom nitrogen di asam nukleat. Cisplatin berikatan dengan residu purin sehingga merusak asam deoksiribonukleat (DNA) sel kanker, mencegah pembelahan sel dan menyebabkan kematian apoptosis sel. Pada kondisi fisiologis, sel mengontrol keseimbangan kadarreactive oxygen species (ROS) dengan 
mengeliminasi menggunakan sistim scavenger (menurunkan glutathione-GSH, dismutase superoksid-SOD, dan katalase-CAT). Namun di bawah kondisi stres oksidatif, terjadi kelebihan ROS yang dapat merusak protein sel, lipid dan DNA sehingga lesi pada sel berkontribusi terjadinya kerusakan sel. Stres oksidatif ini merupakan mekanisme penting dari kerja toksisitas cisplatin. Mitokondria merupakan target utama cisplatin untuk menginduksi stres oksidatif pada sel kanker. Kerusakan yang terjadi akibat stres oksidatif dipicu akibat proses modulasi signalling kalsium, enzim protein kinase $\mathrm{C}$, mitogen-activated protein kinase (MAPK), jun amino-terminal kinase (JNK), p38 mitogen-activated protein kinase (MAPK), dan AKT yang memicu kerusakan DNA sel kanker.
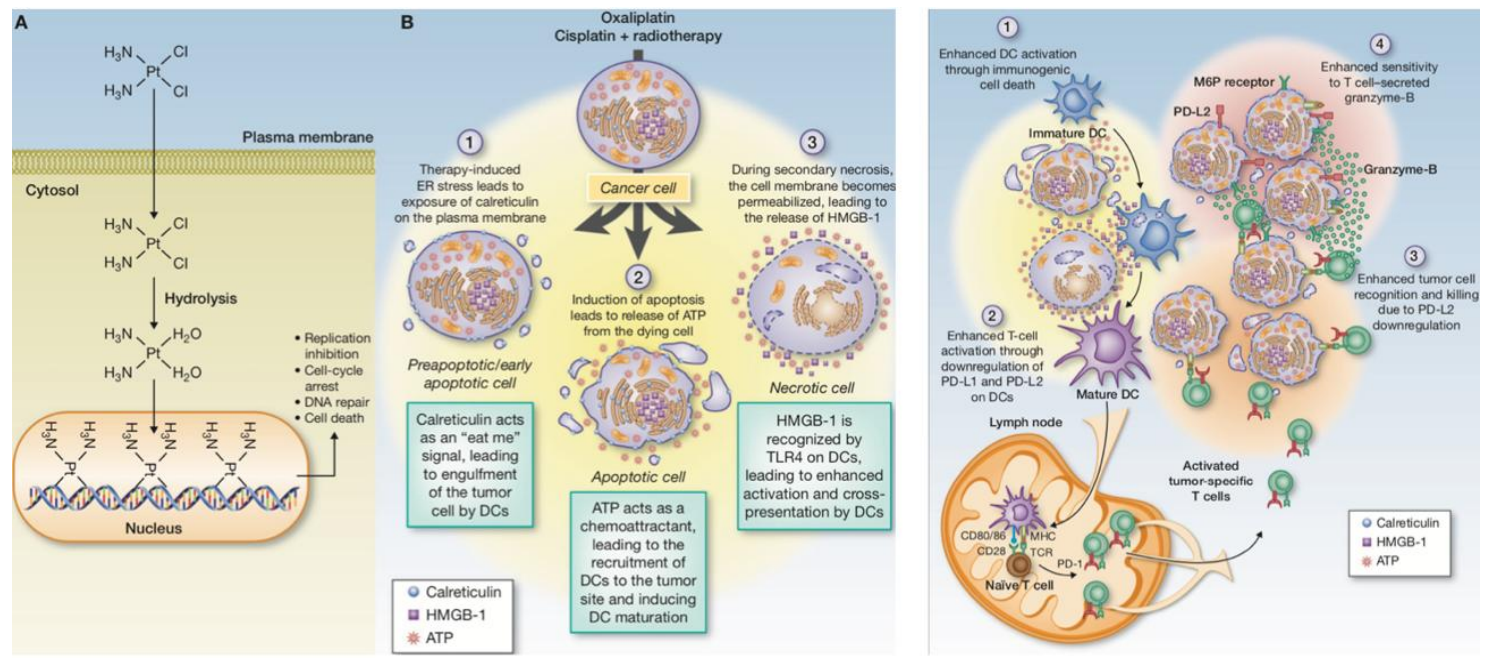

Gambar 1. Mekanisme Kerja Cisplatin Jalur Molekular dan Imunogenik (Hato, S. V, Khong, A., Vries, I. J. M. De, \& Lesterhuis, W. J. 2014)

Pada tingkat selular juga, platinum menginduksi kematian sel secara imunogenik.Pada kemoterapi berbasis platinum terdapat komponen yang efektif untuk memicu sistim imun. Komponen ini menginduksi kombinasi stres pada sel tumor dan kematian sel yang memicu respon imun spesifik tumor. Paparan kalretikulin menyajikan sinyal kepada sel dendrit untuk menelan sel yang mati, dimana pelepasan ATP dan mobilitas kelompok protein-1 (protein nucleus yang meregulasi transkripsi DNA) memediasi aktivasi dan maturasi sel dendrit melalui signalling kepada reseptor, purinoreseptor P2RX7 dan reseptor pengenalan pola TLR4. Oxaliplatin meningkatkan ekspresi MHC kelas I, sehingga meningkatkatkan evasi imun dan mempromosikan maturasi sel dendritik dan proliferasi sel T. Aktivasi sel T terjadi akibat penurunan regulasi molekul penghambat sel $\mathrm{T}$ programmed death ligand (PD-L)2, yang diregulasi oleh interleukin-4 (IL-4)/STAT 6. IL-4 yang berikatan dengan reseptor fosforilasi STAT6 pada sitoplasma diikuti dimerisasi fosforilasi STAT6 dan translokasi ke nucleus dan menginiasiasi transkripsi gen target STAT6 seperti PD-L2. Terapi menggunakan platinum menyebabkan hilangnya fosforilasi STAT6, sehingga PD-L2 turun dan sel T dapat teraktivasi (Hato, Khong, Vries, \& Lesterhuis, 2014).

\section{Mekanisme Resistensi Kemoterapi berbasis Platinum}

Resistensi obat merupakan komplikasi mayor dari kemoterapi kanker dan dihitung sebagai kegagalan kemoterapi untuk menyembuhkan pasien. Resisten terjadi saat sel tumor tidak berespon terhadap obat anti kanker. Resistensi terhadap kemoterapi dapat dibagi menjadi dua kategori besar yaitu intrinsik dan didapat. Resistensi intrinsik menunjukkan bahwa sebelum menerima kemoterapi, faktor-faktor penengah resistensi ada di sebagian besar sel tumor yang membuat terapi tidak efektif. Resistensi obat yang didapat dapat berkembang selama pengobatan tumor yang awalnya sensitif dan dapat disebabkan oleh mutasi yang timbul selama pengobatan, serta melalui berbagai respons adaptif lainnya, seperti peningkatan ekspresi target terapi dan aktivasi jalur pensinyalan kompensasi alternatif (Galluzzi, et al., 2014). 


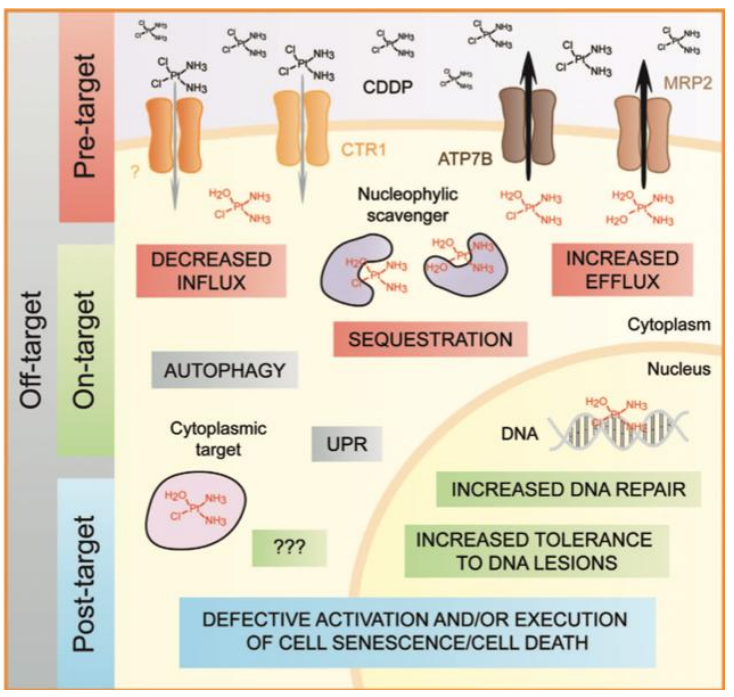

Gambar 2. Mekanisme Resistensi Cisplatin

Beberapa mekanisme yang berkaitan dengan resistensi platinum seperti penurunan akumulasi obat secara intraseluler dan/atau peningkatan efluk obat, inaktivasi obat akibat penurunan thiol selular, perubahan target obat, proses kerusakan yang diinduksi oleh obat akibat peningkatan aktivitas nucleotide excision-repair dan penurunan aktivitas perbaikan-mismatch dan evasi apoptosis (Florea \& Büsselberg, 2011).

Faktor prinsip umum resistensi anti kanker berdasarkan farmakokinetik seperti penyerapan, distribusi, metabolisme dan eliminasi obat yang membatasi jumlah obat yang diberikan secara sistemik yang mencapai tumor. Pada tumor, efek obat pada sel kanker secara kolektif disebut sebagai sifat farmakodinamik. Aktivitas antikanker suatu obat dapat dibatasi oleh masuknya obat yang buruk atau penghabisan berlebihan, inaktivasi obat atau kurangnya aktivasi, perubahan level ekspresi target obat, aktivasi respon prosurvival adaptif, dan kurangnya induksi kematian sel karena apoptosis disfungsional, yang merupakan ciri khas kanker (Holohan, Schaeybroeck, Longley, \& Johnston, 2013).

Sel-sel tumor mengurangi pembentukan aduksi platinum-DNA melalui pengurangan akumulasi seluler obat. Beberapa penelitian in vitro dan klinis telah menunjukkan bahwa konsentrasi platinum dalam sel tumor atau jaringan berkorelasi dengan resistensi platinum. Pengurangan akumulasi platinum seluler dapat menjadi hasil fungsional dari dua jalur independen yang mengatur penyerapan dan ekspor obat intraseluler (Chen \& Chang, 2019).

Resistensi platinum dapat terbentuk pada saat bersamaan dengan perubahan jumlah bentuk platinum yang adekuat di sitoplasma. Platinum dapat masuk ke dalam sitoplasma melalui difusi pasif melewati membran plasma, dengan bantuan transporter tembaga $(\mathrm{Cu})$ yaitu CTR1. Gangguan pada ekspresi kadar CTR1 dan betapolipeptida pada ekspor platinum berkaitan dengan resistensi platinum. Transporter membran plasma lain dipercaya berkontribusi pada penolakan platinum. Sel kanker yang resisten pada platinum dapat mencegah peningkatan GSH, enzim katalis GSH (GST), enzim yang mengkonjugasi, atau metallothioneins sehingga perlawanan terhadap sel tumor dapat berkurang (Holohan, Schaeybroeck, Longley, \& Johnston, 2013; Galluzzi, et al., 2014).

GST membantu dalam pengembangan resistensi obat melalui detoksifikasi langsung dan dengan menghambat jalur mitogen yang teraktivasi protein kinase (MAPK). Peningkatan ekspresi GST dalam sel kanker meningkatkan detoksifikasi obat antikanker, yang menghasilkan kerusakan sitotoksik sel yang kurang efisien. Peningkatan ini juga terkait dengan resistensi terhadap apoptosis yang diprakarsai oleh berbagai rangsangan. Salah satu cara resistensi terhadap platinum dapat terjadi adalah melalui inaktivasi obat oleh methallothionein dan thiol glutathione, yang mengaktifkan sistem detoksifikasi. Perubahan pada protein terkait apoptosis juga dapat menyebabkan resistensi obat. Misalnya, apoptosis dipromosikan oleh protein supresor tumor p53 (TP53), sebagai respons terhadap kemoterapi.TP53 dimutasi pada $50 \%$ kanker, dan ketika mutasi atau penghapusan gen ini menjadikannya tidak berfungsi, resistensi obat dapat mengikuti. Atau, inaktivasi regulator P53, seperti caspase-9 dan kofaktornya, faktor pengaktif protease apoptosis 1 (Apaf-1), juga dapat menyebabkan resistensi obat (Longacre, Snyder, \& Sarkar, 2014; Galluzzi, et al., 2011).

Resistensi pada tahap target berkaitan dengan sensitivitas sel kanker pada efek sitostatik/sitotoksik dari platinum yang terbatas akibat kehadiran organel DNA repair (DDR). Potensi terapeutik dari penargetan mekanisme DDR sangat menarik karena ketergantungan kanker pada mekanisme kompensasi perbaikan. Disregulasi atau kerusakan gen dari mekanisme DDR tertentu baik oleh mutasi atau pembungkaman epigenetik sering terjadi pada banyak sel kanker. Namun, mekanisme DDR lainnya dapat diatur untuk mengkompensasi jalur disfungsional. Meskipun peningkatan aktivitas perbaikan DNA dapat menyebabkan peningkatan resistensi, kompensasi ini juga menyediakan dua peluang untuk kemoterapi. Pertama, menargetkan jalur DDR yang terlalu aktif dengan obat-obatan kemoterapi dapat membuat kanker sangat rentan terhadap obat-obatan yang merusak DNA. Atau, pengetahuan tentang DDR disfungsional dapat 
memungkinkan resep yang tepat dari obat penyebab kerusakan DNA, yang menginduksi kerusakan hanya diperbaiki oleh jalur yang rusak.Dalam kedua strategi kemoterapi, penting untuk mengidentifikasi mekanisme DDR yang terlalu aktif dan kurang aktif. Karena itu menghambat mekanisme DDR ini dapat mencegah resistensi dan membuat sel-sel kanker lebih rentan terhadap agen alkilasi (Longacre, Snyder, \& Sarkar, 2014; Galluzzi, et al., 2011).

Secara umum, sistim ini dipercaya terbentuk akibat lesi DNA yang dipicu oleh kemoterapi berbasis platinum, komponen mismatch repair (MMR) juga diimplikasikan pada proses ini. Sistim ini dipercaya memperbaiki kerusakan DNA akibat platinum, dan terlibat dalam perbaikan sel dan akhirnya menggagalkan terapi. Oleh kareni itu, gen yang mengkode komponen MMR seperti homolog 2 mutS (MSH2) dan mutL homolog 1 (MLH1) sering terjadi mutasi atau yang berkurang aktivitasnya terdapat pada sel yang mengalami resistensi platinum. Sehingga tingginya ekspresi MMR dapat berpengaruh positif pada kedua kejadian yaitu tumor chemotherapy-nä̈ve menjadi relaps (akibat MMR yang membatasi perubahan genetik tambahan) dan kemungkinan neoplasma yang terpapar platinum menjadi kemoresisten. Mutasi MLH1 berkaitan dengan peningkatan sintesis translesi, suatu proses dimana DNA bereplikasi meskipun lesi tidak diperbaiki. Sejalan dengan kejadian ini, defek pada sintesis translesi dihubungkan dengan peningkatan sensitivitas platinum secara in vitro (Galluzzi et al., 2011).

Adisi antar-untai yang diinduksi Cisplatin dapat menyebabkan apa yang disebut kerusakan untai ganda, lesi DNA yang biasanya diperbaiki pada fase $\mathrm{S}$ dari siklus sel (atau segera setelah itu) oleh mekanisme DDR/MMR untuk rekombinasi homolog. Dua komponen penting dari sistem resistensi homolog dikodekan oleh BRCA1 dan BRCA2, dua gen yang sering bermutasi pada kanker payudara dan kanker ovarium. Telah terbukti bahwa resistensi cisplatin dapat berkembang pada tumor cisplatin yang awalnya sensitif karena mutasi sekunder yang mengkompensasi kekurangan BRCA1/2 dan membangun kembali resistensi homolog.Karena katalog interaksi cisplatin yang mungkin terlibat dalam sitotoksisitasnya belum sepenuhnya dijelaskan, protein sitoplasma mungkin juga bertanggung jawab untuk (setidaknya bagian dari) fenotip yang resisten terhadap cisplatin. Sehubungan dengan hal ini, cisplatin telah terbukti mengikat DNA mitokondria serta saluran anion dependen (VDAC), protein mitokondria dengan fungsi vital dan mematikan. Khususnya, sel-sel kanker yang habis VDAC sangat resisten terhadap pengobatan cisplatin, namun tidak jelas apakah ini merupakan contoh resistensi on-target atau apakah dalam konteks ini VDAC hanya mentransduksi sinyal proapoptosis hulu (dan karenanya akan terlibat dalam pasca target mekanisme perlawanan) (Galluzzi, et al., 2011; HZ, et al., 2011).

Pada regulasi kematian sel (apoptosis maupun nekrosis) berada dibawah kendali mekanisme checkpoint dan safeguard, resistensi post-targer dapat berkembang bersamaan dengan perubahan sistem yang mendeteksi kerusakan molekular karena platinum dan merubah menjadi sinyal letal. Sel malignan secara intrinsik lebih resisten pada perubahan lingkungan mikro serta isyarat intraseluler daripada sel non-transformasi dan sangat rentan untuk mendapatkan perubahan genetik dan epigenetik tambahan. Sebagai aturan umum, kondisi stres intrasel (sel yang ditargetkan oleh cisplatin) mempromosikan aktivasi respon adaptif integratif cepat yang bertujuan menjaga keseimbangan sel. Secara umum diikuti oleh emisi anti-apoptotik dan hanya pada saat keseimbangan tidak dapat dipulihkan (kondisi stres yaitu intensitas atau durasi terapi), sinyal letal dimunculkan, de facto menyajikan mekanisme pemeliharaan homeostasis organismal (Shen, Pouliot, Hall, \& Gottesman, 2012).

Namun, resistansi platinum pasca-target telah dikaitkan tidak hanya dengan perubahan genetik dan epigenetik yang mengganggu pensinyalan p53 tetapi juga dengan cacat pada beberapa proyek lain. transduser sinyal apoptosis, termasuk protein kinase teraktivasi mitogen 14 (MAPK14, paling dikenal sebagai p38MAPK) dan c-Jun N-terminal kinase 1 (JNK1). Berbagai aspek resistensi cisplatin telah terungkap dengan pendekatan proteomik. Perubahan pada salah satu faktor yang mengatur dan melaksanakan apoptosis, baik itu dipicu oleh kerusakan DNA atau stres oksidatif melalui jalur mitokondria atau dimediasi oleh rute ekstrinsik, memiliki potensi untuk mempengaruhi sensitivitas cisplatin. Beberapa lusinan protein (termasuk reseptor kematian, adaptor sitoplasma, anggota pro dan antiapoptotik dari keluarga protein BCL-2, caspases, calpains, protein intermembran mitokondria dan banyak lainnya) berpartisipasi dalam kaskade mematikan ini dan kebanyakan dari mereka telah terbukti memodulasi respons terhadap cisplatin (serta sejumlah besar agen kemoterapi lainnya, obat-obatan, racun, dan pemicu stres) secara in vitro (HZ, et al., 2011)

Selain secara selular, faktor fisik juga 
dapat mempengaruhi mekanisme resistensi platinum terhadap sel tumor. Rintangan pertama yang menghambat obat kemoterapi mencapai sel tumor adalah penghalang fisik yang tersusun dari sel tumor yang padat. Hasil eksperimental dari beberapa penelitian menggunakan platform kultur sel tiga dimensi telah menunjukkan kapasitas difusi terbatas dari berbagai obat kemoterapi, termasuk platinum ke dalam jaringan tumor, sehingga mengurangi sitotoksisitas. Selain itu, interaksi antara pertumbuhan tumor yang cepat, matriks ekstraselular sekitarnya, dan pembuluh darah di sekitarnya yang tidak teratur dapat mengakibatkan peningkatan tekanan cairan interstitial, juga disebut fluidic shear stress. Peran fisik matriks ekstraselular bertindak sebagai perancah untuk mempertahankan struktur dan fungsi jaringan.Dengan demikian, matriks ekstraselular adalah pemain kunci dalam perkembangan tumor dan resistensi obat kemoterapi. Perubahan pada kekakuan dan elastisitas matriks ekstraselular dapat membentuk penghalang fisik yang menghambat pengiriman obat ke sel kanker.

Pada faktor biologis, penurunan aliran darah, lingkungan mikro-tumor dan sistim imun mempengaruhi kerja kemoterapi.Agregasi sel tumor yang padat dan aliran darah yang berkurang dapat menyebabkan hipoksia jaringan tumor. Kadar oksigen yang rendah pada lokasi tumor selanjutnya memfasilitasi kebuntuan sel kanker dan pengangkut obat, sehingga menghasilkan resistensi platinum.Selain pengiriman oksigen yang terbatas, kekurangan pasukan nutrisi dari pembuluh tumor yang tidak terorganisir mendorong sel tumor menjadi glikolisis dan produksi limbah yang lebih asam. Lingkungan mikro-tumor (TME) yang asam ini dapat mempromosikan ekspresi transporter multiobat dan juga mengurangi akumulasi platinumintraseluler.

Interaksi antar sel dalam lingkungan mikro-tumor juga merupakan faktor utama yang memberikan resistensi platinum pada sel tumor melalui berbagai mekanisme. Selain CAM-DR, interaksi antara sel stroma dan tumor juga dapat memodifikasi matriks ekstraselular dan faktor pertumbuhan, mendukung angiogenesis tumor, menekan respons kekebalan antikanker, dan karenanya menghasilkan ceruk matriks ekstraselular yang mempromosikan resistensi obat. Fibroblas terkait karsinoma (CAFs) adalah tipe sel dominan dalam lingkungan mikro-tumor, dan hubungannya dengan resistensi platinum telah banyak dieksplorasi. Makrofag terkait tumor (TAM) juga terkait dengan perkembangan tumor dan resistensi obat kemoterapi. Karena peran aktif lingkungan mikro-tumor dalam mengatur perkembangan tumor, menekan resistensi platinum tumor dengan menargetkan terapi lingkungan mikro-tumor mungkin layak (Chen \& Chang, 2019).

Vesikel ekstraseluler (EV) yang disekresikan dapat bertanggung jawab untuk komunikasi antar sel dalam lingkungan mikrotumor. Selain mengekspor obat kemoterapi secara langsung, EV dapat mengatur beberapa proses biologis, termasuk resistensi obat dengan mentransfer bahan biologis yang mengandungnya ke sel target. Hasil ini menunjukkan bahwa selsel tumor yang tertekan dengan pengobatan platinum dapat memediasi resistensi platinum dalam pengobatan lain sel-sel tumor naif melalui komunikasi dengan vesikel ini. Di luar sel tumor, hasil eksperimen baru-baru ini mengungkapkan bahwa eksosom yang dikeluarkan dari CAF dapat mengatur resistensi platinum dalam sel tumor (Chen \& Chang, 2019).

\section{SIMPULAN}

Resistensi yang terjadi pada cisplatin sebagai kemoterapi berbasis platinum terjadi pada tahap pre-target, pada target dan pasca target. Pada tahap pre-target, resistensi terjadi akibat inaktivasi obat, perubahan target dan proses transport obat. Tahapan target terjadi perbaikan DNA sel yang rusak akibat kemoterapi oleh mekanisme DDR dan MMR yang menyebabkan inhibisi kematian sel. Pada tahap post-target, mekanisme yang terjadi yaitu terjadinya mutasi sehingga sel akan resisten. Selain itu, faktor fisik dan biologis juga dapat meningkatkan kejadian resistensi platinum.

Penjelasan ini memberikan gambaran bahwa terapi kombinasi harus menjadi pilihan pengobatan terbaik karena dapat mencegah perkembangan resistensi obat dan menjadi lebih efektif daripada obat mana pun. Oleh karena itu, rejimen pengobatan tersebut harus dipertimbangkan dan dikembangkan untuk menangkal peningkatan prevalensi resistensi obat pada kanker. 


\section{DAFTAR PUSTAKA}

Chen, S., \&Chang, J. (2019). New Insights Into Mechanisms Of Cisplatin Resistance : From Tumor Cell To Microenvironment. Int. J. Mol. Sci. 20(4136), 1-21.

Dilruba, S., \& Kalayda, G. (2016). V.PlatinumBased Drugs: Past, Present And Future. Cancer Chemother Pharmacol. 77(6), 1103-1124..

Florea, A., \& Büsselberg, D. (2011). Cisplatin As An Anti-Tumor Drug: Cellular Mechanisms Of Activity, Drug Resistance And Induced Side Effects. Cancers. (3), 1351-1371.

Galluzzi, L., Senovilla, L., Vitale, I., Michels, J., Martins, I., Kepp, O., ... Kroemer, G. (2011). Molecular Mechanisms Of Cisplatin Resistance. Oncogene. 31(15), 1869-1883.

Galluzzi, L., Vitale, I., Michels, J., Brenner, C., Szabadkai, G., \& Castedo, M. (2014). Systems Biology Of Cisplatin Resistance: Past, Present And Future. Cell Death And Disease. 5(5), E1257-18.

Hato, S. V, Khong, A., Vries, I. J. M. De, \& Lesterhuis, W. J. (2014). Molecular Pathways: The Immunogenic Effects Of Platinum-Based Chemotherapeutics. American Association Fo Cancer Research. (1), 2831-2838.

Holohan, C., Schaeybroeck, S. Van, Longley, D. B., \& Johnston, P. G. (2013). Cancer Drug
Resistance: An Evolving Paradigm. Nature Publishing Group. 13(10), 714-726.

HZ, Z., YQ, Q., WJ, Z., B, X., AM, D., \& LiangAB. (2011). Proteomic Analysis Identified DJ-1 As A Cisplatin Resistant Marker In Non-Small Cell Lung Cancer. Int J Mol Sci, (12), 3489-3499.

Kelland, L. (2007). The Resurgence Of PlatinumBased Cancer Chemotherapy. Nature. 7 (AUGUST), 573-584.

Longacre, M., Snyder, N., \& Sarkar, S. (2014). Drug Resistance In Cancer: An Overview. Cancers, (6), 1769-1792.

Martin, L. P., Hamilton, T. C., \& Schilder, R. J. (2008). Platinum Resistance: The Role Of DNA Repair Pathways. Molecular Pathways, 14(5), 1291-1296.

Oun, R., Moussa, Y. E., \& Wheat, N. J. (2018). The Side Effects Of Platinum-Based Chemotherapy Drugs: A Review For Chemists. Dalton Trans, 47(19), 66456653.

Shen, D., Pouliot, L. M., Hall, M. D., \&Gottesman, M. M. (2012). Cisplatin Resistance: A Cellular Self-Defense Mechanism Resulting From Multiple Epigenetic And Genetic Changes. Pharmacological Reviews, 64(3), 706-721. 